\title{
Customer decision-making process and the effect of marketing on the final purchase decision
}

\author{
Vishesh \\ PhD Research Scholar, GGS IP University, New Delhi, India
}

*Corresponding Author:

Email: vishesh.singh@gmail.com

\begin{abstract}
The paper aims to explain the consumer decision process and evaluate the various marketing channels used by the firms to influence the decision process of the consumer. The first part of this paper critically reviews the customer decision process by analysing the stages of the process which are a) Problem recognition b) Information gathering c) Evaluation of alternatives and d) Customer purchase decision. Subsequently various patterns of buying behaviour formed as a result of the purchase decisions made by the customer in the case of products are explained. The second part seeks to look at the efforts on the part of the marketer to market their product including advertising, packaging, pricing, differentiation and product distribution.
\end{abstract}

Keywords: Buying behaviour, Customer decision-making process.

\section{Introduction}

Now that we have completed an assessment of the factors which influence the consumer's decision making. We shall proceed to the actual decision process and how the decision process takes place in consumer households. Post the study of factors, the marketers must try to trace the whole buying process and it starts with determining who makes the buying decision.

Kotler (2008) finds five roles in the decision making exercise which are a) Initiator - the person who suggests the idea to the prospective consumer $b$ ) Influencer - the person who influences the purchase c) Decider - the person who decides on the product d) Buyer- the person who makes the purchase and e) Userthe person using the product. It is very important for the marketers to know who is what in this chain of roles within a community. For instance, in the village scenario, the sarpanch or the headman may be a key influencer for a group of families. Kashyap and Raut (2010) agree that opinion leaders exert a much greater influence and they influence and initiate for a range of products that reflect their lifestyle and social status within the society. They act as the 'trend setters' and the positive word of mouth and the marketers need not look much further to try to make giant leaps in their rural sales. But this is again complicated by the existence of rural brands which have dominated the scene and the influencers and initiators may be reluctant to change their behaviour unless the benefits become very clear.

We should come down to the decider and buyer once the stimuli have been created by the influencer or initiator. An analysis of the decider in the Indian context throws up very interesting questions. Firstly, the cultural factors and the male dominance from the hierarchical social stratification has not completely gone away in the Indian society. Pradeep Kashyap (2005) comments that men make the decision due to the lack of mobility of women in rural India but the urban picture is different with involvement from wife and children and purchase decisions. Freda (1995) observed that for the purchase of consumer durable goods, the family members together decide on the product to be purchased, brand and shop. Decisions may usually be taken by women in the case of products that they use and it presents the marketer with the hard task of trying to gauge the percentage of situations where the buyer is different from the decider. If the decider is different, it may not be a good strategy to communicate to the buyer because he/she will have no say in further purchase of the product. It is worth noting that user also may be different in the rural economy as the males normally buy goods for the children and the women to use and this dynamic is further complicated in joint family scenarios.

\section{Consumer Buying Behaviour}

Looking at the behavioural patterns shown by consumers would be a good way for a marketer to understand the needs of the consumers, how consumers take decisions and how these decisions manifest into brand choices over a longer period of time. There are various types of consumer behaviour which the consumers exhibit. They are:

\section{Complex Buying Behaviour}

Consumers exhibit complex buying behaviour for high-involvement products like high-priced consumer durables. The consumer goes through the whole process of identification of the problem, consultation and assessment of the factors and the alternatives in the brands for the product. We found that Sirgy (1972) explained how complex the understanding of the motivational factor can prove to be in the analysis of factors influencing consumer behaviour. Skinner (1990) opined that when a consumer purchases an unfamiliar expensive product he uses a large number of criteria to evaluate alternative brands and spends a great deal of 
time seeking information and deciding on the purchase. The type of decision making used varied from person to person and from product to product. However, when it comes to the evaluation of alternatives, Bettman (1979) feels that customers rarely analyse the complex alternatives in decision making and apply very simple strategy. Gaur and Vaheed (2002) observed that consumers' buying behaviour normally should include the less observable decision process that accompanies consumption including where, how often and under what conditions consumers make their purchase of desired goods and services. The rural area in India is fast changing and beginning to exhibit buying conditions facing urban areas to an extent, making it hard to predict whether the consumer goes through extensive consultative process for products.

It has usually been observed that the more expensive and infrequent buys like consumer durables make the consumers want to go through a long process before making the purchase decision. First, the consumer would develop beliefs about the product and this is where the opinion leaders and initiators. According to Kotler (2008), the marketer has to make the pitch with regards to the more important attributes of the product. The marketer should seek to assist the buyer in understanding about the major attributes of the product and track the information-gathering sources of the consumer.

\section{Dissonance Reducing Behaviour}

This is where the consumer shows the tendency to buy very quickly. The advertisements can have a very sudden impact on these buyers the products may not have much difference in their character like mattresses and other furniture. The marketers need to just focus on the element that creates an impression in their minds about the product as they tend to stick on to the same product if they satisfy their primary belief and don't have many 'dissatisfiers' in their features. The marketing strategy should be to make sure that the consumers feel good about the choice they made as they make the choice before acquiring the beliefs. Since buyers in developing countries would not show likelihood to experiment too much unless the brand has too many dissatisfiers, it is important that the marketers focus on the positive aspects to make them feel good and persuade a good word of mouth for the product.

\section{Habitual Buying Behaviour}

We do have many products especially the low involvement, inexpensive, fast-moving consumer goods with low involvement where consumers develop habits in their buying behavior. Consumers do not form a strong positive belief about a brand but they go by how familiar they are towards the brand. They may not even be bothered too much post-purchase because the product is not a high-involvement one because of the inexpensive nature of them. It could be argued that the income constraint facing the Indian consumer is so much that they will be trying to gain value out of every penny they spend. But we should look at the relatively inexpensive goods in the consumer basket that have the characteristics of a product where you could build a habitual behavior. However, we have to recognize that the considerations for 'involvement' would vary depending on the context or circumstance and the context would be consistent with the factors affecting consumer behavior in the region under consideration. Jayasankar (1995) while examining the performance of BPL found that despite the minor role played by impulse in the purchase decision of consumer durables, emotional involvement had also been found important in recent years. Involvement here refers to the personal relevance or importance of a product or service that a consumer perceives in a given situation.

Kotler (2004) explains that marketers are better off using price promotions as the consumers do not have particular attachment to a specific brand. He goes on to list four ways the manufacturer could use to attract customers to their products. They could

1. link the product to an issue (like sunburns or lack of skin tone)

2. link it to a personal situation

3. design the advertisement to trigger emotions

4. they add a distinguishable feature to the product

W.K. Sarwade (2002) and S. Kulloli (1995) agree that price is indeed a major concern for rural consumers. So, we can assume that habitual buyers of products are going to be influenced by price and sales promotions especially in the fast moving consumer goods sector.

\section{Variety Seeking Consumer Behaviour}

Some low involvement products are however characterised by great differences in brands available for consideration with many different attributes and benefits. It is estimated that consumers especially consumers who are open to experimental consumerism switch a lot between different brands. Marketers need to be open to the needs of the consumers by ensuring that their products are in stock in areas where variety seeking behaviour is predominant. Variety seeking behaviour is encouraged through advertising and also free offer of samples. The offer of free medical samples is a very relevant example as the products have different brands and the consumers may look for newer products in the health sector. Differentiation within the brand is very important as customers are very receptive to the idea of variety in the product that they consumer and not variety necessarily in terms of the brand.

We have established how the involvement and brand choices in the buying behaviour pattern a consumer is likely to develop. The following table has been adapted from: Krishnamacharyulu and Ramakrishnan (2011) Pg 135 
Table 1

\begin{tabular}{|l|c|c|}
\hline $\begin{array}{l}\text { Differences } \\
\text { among brands }\end{array}$ & $\begin{array}{c}\text { High involvement } \\
\text { level }\end{array}$ & $\begin{array}{c}\text { Low involvement } \\
\text { level }\end{array}$ \\
\hline Significant & Complex & Variety \\
\hline Low & Dissonance reducing & Habitual \\
\hline
\end{tabular}

\section{Customer Decision Framework}

Before we conduct an analysis of the various factors directly affecting the buying behaviour of consumers, the process of consumer decision making needs to be explained briefly. It is to be noted that not all the products strictly go through the whole process of consumer decision making

a) Need Recognition: When the buyer recognizes a difference between the ideal state and the actual state due to the stimuli created by his own though process or external stimuli, he may decide to act on it by taking his interest further. The marketer should draw the consumer's attention to potential needs which would take the consumer to a higher consumption level within his income constraint.

b) Information Search: On recognising a need, consumers try to gather information on the different alternatives. Sarangpani (2008) claims that information search is a more critical process for durable products as compared to non-durable products. Kotler (2008) in his analysis of the different types of buying behaviour explains the difference between the length of information search between low involvement and high involvement products. There are many sources for the consumer to gain the required information for the product category. They can be classified as personal, commercial, public and experimental or handling. Personal sources are usually family, friends and other acquaintances. Nelson (1970) concludes that personal sources are more trusted for experience goods and not non-personal search goods. Commercial sources would be advertising, salespersons, dealers, packaging and displays. Public sources include media like the internet and standards organisations. For a consumer, the experimental sources are the experience of handling or using the product once. Experience would in turn lead to the consumer exhibiting behavioural patterns with that product. Anderson et al (1979) has highlighted the inverse relationship between the amount of product experience and external search. So the more experience a user gets, it is reasonable to assume that he is more likely to stick to it and restrain from external alternative search.

The consumer would also possibly have knowledge acquired about the product prior to the stimuli. Generally, there is an inverted U shaped relationship between prior knowledge and the search he would undertake in the current process. However, Merrie Brucks (1985) explains that it is the objective prior knowledge which will add more value over subjective prior knowledge during the search process. Prior product knowledge is also observed to enhance search efficiency for the product even with a limited search extent. A key factor which influences the extent of search as clearly outlined in Jacoby et al (1974) is the cost of the search process. If the cost (or even time) of search is perceived to be greater than the marginal difference in price between two products, the consumer may not find it worthwhile to carry out a search at all.

c) Evaluation of Alternatives: Once the consumer has conducted the gathering of information, he/she shall proceed to evaluate the different alternatives that came up during the search, Krishnmacharyulu and Ramakrishnan (2011) classifies this process as the customer's efforts to narrow the options down from the awareness set to the consideration set and finally to the choice set. This is yet another stage when the consumer is open to influence by the marketer's attempt to catch his attention with their superior attributes. Again, this process is substantially longer when the price of the product involved is higher. The opinion leaders have an important role to play in this situation.

d) Buying Decision and Post-purchase Behaviour: The consumer exercises the decision to purchase the product. Kotler (2008) commented that even postdecision making; he can be influenced by others who may point out a specific attribute of a product in his choice set prompting him to re-evaluate before he makes the purchase. Once the purchase is made, the consumer develops a relationship with the product and the marketer needs to tap into this relationship and make this stronger. The development of brand loyalty and word of mouth among others are vital for the growth of sales especially in closely connected markets like the Indian rural and sub-urban markets.

\section{Strategic Marketing as a Driver of Customer Decision Making Process}

One of the major determinants of consumer product choice is the information the consumer has received while searching for the product. Noel (2009) states that consumers usually make decisions based on the information stored in their memory about the product. Moreover, knowledge is a result of the associations and linkages we give to different objects. Marketing strategists try to define what the product is associated with depending on the consumers they would want to attract to use their product. Firms also resort to product differentiation and tailored advertisement/promotions for different market sections for the same product to enhance their reach and sales. The ways in which firms use marketing can be divided into three categories a) Product and Packaging b) Advertising c) Pricing and Distribution. Firms take into consideration different factors while approaching each of these marketing categories and we shall go into detail into each one of them and see how consumer behaviour is influenced by marketer's activities and how effective strategic marketing is in shaping consumer perception about the product or service. 


\section{Product Differentiation and Packaging}

The best medium to carry out the marketing strategy would be the product itself as it gives direct cue to the consumer and is the most effective in terms of returns for the producer. When it comes to the product, packaging and product differentiation are the major ways of product marketing.

The product differentiation is seen as a very good sign as it is perfect competition or somewhere close to perfect competition that drives companies to innovate in terms of how their product looks or is structured. Porter (1976) held that product differentiation would contain physical and non-physical characteristics. Chamberlin (1953), one of the earliest economists to study product demand in the marketing sense, defines product differentiation as 'distinguishing the goods or services of one seller from those of another on any basis that is important to the buyer and leads to a preference'. Chamberlin went on to comment on how the basis of differentiation could be real or imagined and wrote about the role of brand name and brand perception in product differentiation.

Shaked and Sutton (1982) analysed product competition and observed that while price would vary based on market conditions, product differentiation would be the appropriate process to gain the market share when competition is high. Product differentiation is often confused by marketers with the concept of market segmentation and there is a need to distinguish between these concepts and also understand if these are alternative strategies or complementary strategies. Smith (1956) continued with Chamberlin's and Robinson's demand oriented explanations of the concept of product differentiation. Smith (1956) sees product differentiation as a function of the convergence of individual market demands calling for various producers of the same product to differentiate even while offering more or less the same attributes. Dickson and Ginter (1987) tried to explain the concepts of market segmentation and product differentiation and the crucial role they play as vehicles of modern day marketing. They also seek to differentiate between the concept of product differentiation and market segmentation as they found that the general opinion hitherto was that segmentation was used as a marketing tool when differentiation was hard to be practised. The writers conclude that product differentiation and market segmentation must not be seen as alternative marketing strategies. A product differentiation strategy can happen even without any market segmentation but market segmentation would need a product differentiation strategy to exist. Interestingly, Martins, Yousuf and Swanson (2012) see product differentiation as a feature of market segmentation. Marketers and managers need to however make sure that there is scope for differentiation in the sector by trying to track consumer expectations and market size. According to them, product differentiation would comprise of producers differentiating the same good to tailor their modified product in response to the different perceptions behaviour of people with different characteristics from different market segments by introducing the new term 'social differentiation'.

Product differentiation strategy needs to be more consumer-oriented so that both businesses and consumers can gain more from the differentiation of the product. Product differentiation is also important for the sector to grow as more producers for the same good will seek to innovate and stay in the sector. Product differentiation is employed both by established brands and new entrants. While the new entrants may differentiate the product to gain the market with already established brands, already established brands try to market how they are different from those out there by introducing more products which have specific qualities like a nutrient or a chemical with a distinct quality that would make them stand out in the market. Schmalensee (1982) compared the relative advantages or disadvantages of differentiation pursued by established pioneering brands and newer entrants in the market. Their study revealed that there is a product differentiation advantage of early economies irrespective of rationality or advertising. An economic analysis conducted in Schmalensee (1982) found that long-established brands do have significant demand advantages due to the customer's perception and experience.

The product packaging is indeed a very key element in the product perception and image the company wants to convey to the larger audience. According to Singh and Singhal (1986) a well designed packaging acts as the main identifying feature for quality and quantity and make the consumers more informative and choosy. Kashyap and Raut (2010) and Krishnamacharyulu and Ramakrishnan (2011) cite many instances in the Indian rural context when duplicate products have gained a major chunk of the market. Kotler (2008) suggests that packaging should be identifiable with specific colour as they may not be able to read and identify with the colour or images. Go for fewer frills when customers go toward functionality. Marketers need to communicate properly about copycats.

Packaging can be that factor which could differentiate the products from the others at the point of sale. Schoormans and Robben (1996) acknowledge the fact that changes in appearance of a product can influence the stimuli of the product. Yang and Priya (2004) conducted a study on beer bottle shapes and found that bottle sizes affected the purchase and longer bottles with the same amount would mean less is purchased. But for someone making a single purchase, the longer bottle would be preferred to a can as the predominant consumer perception is that longer bottles contain more beer. Ares and Deliza (2010) carefully investigated the driving forces behind customer 
decision making in the purchase of packaged milk desserts to conclude that package colour affected texture expectations. The study proved that the positive influence of a well-designed package can be extended to the packaged food sales as well. A participant observational study conducted by L.E. Wells et al (2007) at two Tesco supermarket stores in the UK. To narrow the background of study, the research was limited to own-label food brands in this case. The research exercise found that almost three-fourths of the customers used packaging as an attribute to decide on their product from the food brands. Extrinsic attributes are therefore a very important factor in the quality assessment of own-label food brands.

Packaging is definitely emerging as a very vital component in the marketing strategy as more attention and research is developed to know about how appearance can induce positive stimuli. Prince (1994) states that small changes in package design can cause a big difference in sales in an era of over-promotion and shrinking real incomes. Sehrawet and Kundu (2007) studied the effect of package design in India and found that even though gradually the rural consumers in the state of Haryana are shifting from loose to packaged goods as they help in identifying the product. Rural population also was seen as responding to more catchy packaging design and held the belief that better packaging contained better products. The study concludes that the winners will be the companies who could adapt and tailor their communication to the rural consumers needs.

The design of packaging is therefore a process which must go through scientific behavioural research. Gofman et al (2010) assesses in detail the concept of Rule Development Experimentation (RDE) in the designing of packages to attract optimum sales. RDE is a solution oriented business process of optimisation which designs, tests and modifies alternative ideas in the creation of product, packages or services. The study finds that consumers need to be co-involved in the design of the package and also stresses the importance of health messages and pictorial representation, both of which were viewed favourably by the respondents in the study. At a time of growing ethical and environmental consciousness, we are witnessing more and more products declaring their commitment to values like recycling and declaring their environmental footprint in the package. Brand cynicism is gradually becoming a feature among upper middle class consumers and ethical marketing and Corporate Social Responsibility (CSR) will address this reputational deficit.

\section{Advertising and Promotions}

Advertising and packaging exert a great deal of influence in the buying habits of consumers around the world. Bhavani Prasad and Sitakumari (1987) found that advertising is a major influencing factor in the customer's decision process. Advertising can be used to create brand images and appeals about a brand especially when it becomes hard to differentiate between their functional values and attributes (Belch and Belch, 2003). Traditionally, functional value is presumed to be the primary driver of consumer choice. This assumption underlies economic utility theory advanced by Marshall (1890) and Stigler (1950) and popularly expressed in terms of "rational economic man.". Chiu et al (2006) identifies advertising strategy as one of three central strategies along with product and marketing strategy. By identifying the dominant function of a product (i.e., what benefits it provides), marketers can emphasize these benefits in their communication and packaging. Advertisements relevant to the function prompt more favorable thoughts about what is being marketed and can result in a heightened preferences for both the ads and the product, (Solomon 1996;160).

Verma and Israney (2000) conducted a survey to find out the consumers' attitude towards the advertisement messages revealed that the general attitude of the majority of consumers is favourable towards advertisement messages. They also pointed out that it is not easy for advertisers to persuade adult consumers to shift their brand preferences based on product advertisement alone. Advertising can also change the behavioural pattern exhibited by the consumers in the buying process. For instance, advertising can point out common dissatisfiers exhibited by a rivals product and change the dissonance reducing behavior of the consumer into seeking a different product. Mela et al (1997) opines that companies turning to advertising from price promotions as the focus on price promotions was seen to make them price conscious and not brand conscious. As expected, in the long run price promo-tions make consumers more price sensitive in both the loyal and non-loyal segments. Non-price promotions only affect the price sensitivities of the consumers. How a certain consumer responds to advertising pitches are communication are dependent on many psychological, cultural and cognitive factors. Haugtvedt et al (1992) stated that differences in need for cognition represent differing tendencies to engage in thinking. This was seen to have an influence on the effect of advertising on the population. The study went on to differentiate between the low need for cognition individuals and how they behaved was demonstrably different from high need for cognition individuals. For the marketer, the communication channels being chosen to advertise are very important and they could either be personal or non-personal communication channels.

In terms of advertising, you could use print or electronic media to get your message across to the buyers. K.R.I Sathya Sundaram (2002) in his study on washing machine advertising in India comments that the rural population is being influenced by television 
advertisement campaigns. This could be because of the lower literacy rates and also about visual representations getting more selective attention in the rural context. All the factors that influence consumer behaviour should be considered in the designing of communication strategy of a given product. Bertil Naslund (1979) suggests the usage of the consumer bahviour theories in the design of an optimal advertisement policy. It is added that advertising policies have more reach in the early life of a product. However, the short-run and long run effects of advertising messages may vary depending upon the context and the adaptability of the marketing strategy to reflect changes in the factors affecting consumer behaviour. Erdem and Keane (1996) observe after running policy experiments that advertising intensity has only weak short run effects, but a strong cumulative effect in the long run. Other factors influencing consumer behaviour like culture and lifestyle need to be captured in advertising strategy formation. Marike De Mooij (2003) warns against the formulation of a global advertising policy for products as cultural differences need to be appreciated. Bigger brands have taken this to heart by having different advertisements in areas depending on the demographics and the social class. For instance, they would use symbols that appeal to African American population when they advertise through media that are predominantly used by those sections of the population. Marike De Mooij (2003) however comments that there are some products including very expensive consumer durables with less number of consumer around the world where converging and standardised marketing policy may work.

Advertising has gone hand in hand with the economic situation in India during the postindependence period. William M O'Barr (2008) has identified four stages in advertising post independence. The first stage was between 1947 and 1960 when it served as an outpost of the empire and there was a general lack of creativity. The second stage emerged in the 1960s for around two decades and stressed on cultural identity and creativity. The 1980s saw a third face which left creative advertising strategy and focussed on building marketing channels. From the 1990s onward, we have seen a complex strategy which is a mix of effective marketing and high levels of creativity.

O'Barr (2008) also explains in detail about the media used by companies for marketing purposes. There is recognition that India has an expanding population dependent on the internet and major brands are already turning into digital marketing. Mass communication is indeed a huge shift from the previous marketing modes like print media and billboards. Another form of marketing which should be kept in mind for the future is viral marketing through internet and chat media. Cosmetic products like Lux and fair and lovely do have their own chat rooms but these need to be constantly monitored and product perception needs to be tracked. Joseph E. Phelps et al (2004) found that viral marketing does show very interesting behavioural aspects about consumers and how they respond to forwarded marketing and advertising messages and the likelihood of them passing the message on to someone else. The communication needs to be open and honest. Viral forwarded messages from a trusted friend or colleague may be credible as the communicator wants to help and educate (pro-social) rather than just pro-business.

\section{Pricing and Distribution}

The most important marketing strategy that would influence the most economically rational consumer out there is the price of the product. Rao (1984) considers pricing related promotion to be a very potent marketing strategy for increase in sales and revenue. Marketers need to have a pricing strategy that would work both for the business in terms of the raw materials and other costs and the consumers who would be attracted to buy its product over others. Samiee (1987) lists two reasons why pricing should be an important variable in marketing. Firstly, prices are the means deciding all the major variables including revenue and profits making it vital for the survival and long term prospects of the firm. Secondly, pricing is the only marketing element the company can control without making a large investment. Pricing is therefore a very vital short term tool. Especially in the aviation industry, we have seen pricing wars that have driven the price down drastically in India in the last few months.

Many studies on consumer behaviour including Chiu et al (2007) and Kishore and Nabi (1997) have revealed the central role price plays in influencing consumer behaviour. The setting of price is therefore something that should involve the marketer as well if the company needs to stay in touch with its competitors. The pricing strategy of a firm will be largely dependent on the nature of the market the firm operates in. For instance, a firm may pursue a different strategy if it is a monopoly to the strategy it would employ in a competitive market.

Another way to respond to the factors influencing consumer behaviour decision process is through the distribution of the product. The channels of distribution can be a good way to integrate the marketing objectives aimed at different sections of consumers. Bowersox and Morash (1989) list eight basic flows that are essential in the marketing of distribution and supply chain. They are possession, ownership, promotion, negotiation, financing, risking, ordering and payment. The article states that marketing strategies of distribution are implemented by forming activity flows. Activity flows therefore need to be organised in a channel of distribution to implement order attributes to satisfy consumer demand and expectations. 
The distribution channel needs to be managed properly for optimum distribution and for the success of marketing strategies. Weitz and Jap (1995) identify relationship marketing as a means of distribution channel management. Their study revealed three control mechanisms to control and coordinate distribution channels namely authoritative, contractual and normative. Authoritative management involves one party using its power or position to control other parties. Contractual control involves an agreement by the parties or divisions or franchises defining the responsibilities in different stages of the distribution process. Normative control mechanism has the parties sharing a set of principles that govern the activities performed by each arm of the business.

On the ground, distribution is all about knowing the demand and requirements of the market the firm is distributing for. Kashyap and Raut (2010) stress that marketers need to maximise direct flows and control of stocks in the market to further their sales. Channels of distribution will also differ depending on the structure of the company and the nature of the product. They also identify wholesale and retail as the two modes of distribution. In terms of essential goods in India, consumer also has the alternative option to buy from the government run distribution scheme called the Public Distribution Scheme (PDS). Such schemes are more prevalent in less developed economies to provide food security to the poorest.

Finally, companies can influence their market perception and featuring among consumer's alternatives by understanding the dimensions of the distribution channel. Kashyap and Raut (2010) enlist nine such dimensions each of which should be considered in detail by the marketer in their attempts to influence the decision process of the consumers. They are a) Credit facilities or instalment facilities b) pricing in the channel c) Reason for stocking d) Seasonal factors for stocking e) Influence of the retailer on the consumer f) retailer purchase source g) channelling of credit $h$ ) purchasing cycle i) channel promotion. Focusing individually and collectively on each of these nine dimensions should be the objective of the marketing policy as far as the distribution is concerned.

\section{Conclusion}

The customer decision framework is a very important source for a marketer who aims to design the ideal marketing strategy for the firm. There need to be specific research on how each element of the decision process can be influenced by marketing strategies. More behavioural research will also shed light on the psychological and economic motivations behind the thought process of the consumer as he goes through each stage of the process. Also, how consumer behaviour is formed also has a great influence on marketing. For instance, a product or brand which features most in the list of variety seekers will need to design its distribution strategy in such a way that it reaches most outlets in both rural and urban areas.

The consumer's behaviour and the decision process are greatly influenced by how the company can create cues and impressions on the consumers. The efforts on the part on the firm to stimulate the consumer and make them consider their product and its benefits are implemented through the firm's marketing strategy. There need to be more context based research and field surveys on how each method of marketing would influence consumer behaviour especially in rural contexts where firms face several challenges to access or establish their stronghold in the market. However, we could conclude that each channel or method has its importance and should be a part of a comprehensive marketing strategy assessing at what stage each method would be taking effect.

\section{References}

1. Sarangpani (2008) 'A Textbook on Rural Consumer Behaviour in India - A study of FMCGs.

2. Alfred Marshall (1890) Principles of Economics: An Introductory Volume. MacMillan, London.

3. Anderson, R. D., Engledow, J. L., \& Becker, H. (1979). Evaluating the relationships among attitude toward business, product satisfaction, experience, and search effort. Journal of Marketing Research. 394-400.

4. Ares, G., Deliza, R. Studying the influence of package shape and colour on consumer expectations of milk desserts using word association and conjoint analysis. Food Quality and Preference. 2010;21(8):930-937.

5. Belch, G. E., Belch, M. A. (2003). Advertising and promotion: An integrated marketing communications perspective. The McGraw- Hill.

6. Bettman, J. R. (1979). Information processing theory of consumer choice.

7. Bettman, J. R. (1979). Memory factors in consumer choice: A review. The Journal of Marketing. 37-53.

8. Bhawani Prasad and Seethakumari, K. Impact of advertising on consumer durable market. Indian $J$ Market. 1987; 18:21-28.

9. Bowersox, D. J., \& Morash, E. A. The integration of marketing flows in channels of distribution. European Journal of Marketing. 1989;23(2):58-67.

10. Brucks, M. (1985). The effects of product class knowledge on information search behavior. Journal of Consumer Research. 1-16.

11. Chamberlin, E. H. (1953). The product as an economic variable. The Quarterly Journal of Economics. 1-29.

12. De Mooij, M. Convergence and divergence in consumer behaviour: implications for global advertising. International Journal of advertising. 2003;2(2);183-202.

13. Degeratu, A. M., Rangaswamy, A., \& Wu, J. Consumer choice behavior in online and traditional supermarkets: The effects of brand name, price, and other search attributes. International Journal of Research in Marketing. 2000;17(1):55-78.

14. Dickson, P. R., \& Ginter, J. L. (1987). Market segmentation, product differentiation, and marketing strategy. The Journal of Marketing. 1-10.

15. Erdem, T., \& Keane, M. P. Decision-making under uncertainty: Capturing dynamic brand choice processes in turbulent consumer goods markets. Marketing science. 1996;15(1):1-20. 
16. Freda Gnana Selvan. New year discount sale - The psychology of price. Indian J Market. 1995;24:11-15.

17. Gaur SS, Vaheed KA. Study of buying behavior for branded fine rice: Indian Journal of Marketing. 2002;32(7)

18. Gofman, A., Moskowitz, H. R., \& Mets, T. Accelerating structured consumer-driven package design. Journal of Consumer Marketing. 2010;27(2):157-168.

19. Haugtvedt, C. P., Petty, R. E., \& Cacioppo, J. T. Need for cognition and advertising: Understanding the role of personality variables in consumer behavior. Journal of Consumer Psychology. 1992;1(3):239-260.

20. J Skinner (1990) Customer Participation in Service Production and Delivery. Journal of Retailing. 66(3)

21. Jacoby, J., Speller, D. E., \& Berning, C. K. (1974). Brand choice behavior as a function of information load: Replication and extension. Journal of consumer research, 33-42.

22. Jayasankar, M. A fresh bounce. A\&M J. 1995;7:30-34.

23. K R I Sathya Sundaram (2002) Washing machineries opportunities; Facts for You 21 (9).

24. Kashyap Pradeep (2005) 'Selling to the hinterland' In Tony Joseph, The Marketing Whitebook. New Delhi: ABP Pvt. Ltd.

25. Kotler Philip (2004) Marketing Management - Analysis, Planning, Implementation and Control (Ninth Edition).

26. Kotler Philip (2008) Marketing Management - Analysis, Planning, Implementation and Control (Ninth Edition).

27. Krishnamacharyulu, C. S. G. and Laltha Ramakrishnan (2011). Rural Marketing: Text and Cases, 2/E. Pearson Education India.

28. Martins, J. M., Yusuf, F., \& Swanson, D. A. (2012). Market Segmentation and Income Distribution. In Consumer Demographics and Behaviour (pp. 111-132). Springer Netherlands.

29. Mela, C. F., Gupta, S., \& Lehmann, D. R. (1997). The long-term impact of promotion and advertising on consumer brand choice. Journal of Marketing Research. 248-261.

30. Näslund, B. (1979). Consumer behaviour and optimal advertising. Journal of the Operational Research Society. 237-243.

31. Nelson, P. (1970). Information and consumer behavior. The Journal of Political Economy. 311-329.

32. Noel, H. (2009). Basics marketing 01: Consumer behaviour (Vol. 1). AVA Publishing.

33. O'Barr, W. M. Advertising in India. Advertising \& Society Review. 2008;9(3);1-33.

34. Phelps, J. E., Lewis, R., Mobilio, L., Perry, D., \& Raman, $\mathrm{N}$. Viral marketing or electronic word-of-mouth advertising: Examining consumer responses and motivations to pass along email. Journal of advertising research. 2004;44(04);333-348.

35. Porter, M. E. (1976). Interbrand choice, strategy, and bilateral market power (No. 146). Harvard University Press.

36. Pradeep Kashyap and Siddhartha Raut. (2010) The Rural Marketing Book.

37. Prince, Greg W (1994). The contour: A packaging vision seen through Coke-bottle lenses. Beverage World, 113 (1567, Periscope Edition, May 31):1,6.

38. Rao, V. R. (1984). Pricing research in marketing: The state of the art. Journal of Business. S39-S60.

39. S. Kulloli (1995) Clothing consumption pattern of rural and urban families: Msc Thesis University of Agricultural Sciences, Dharwad.
40. Samiee, S. (1987). Pricing in marketing strategies of USand foreign-based companies. Journal of Business Research. 1987;15(1):17-30.

41. Schmalensee, R. (1982). Product differentiation advantages of pioneering brands. The American Economic Review, 349-365.

42. Schoormans, J. P., \& Robben, H. S. The effect of new package design on product attention, categorization and evaluation. Journal of Economic Psychology. 1997;18(2):271-287.

43. Sehrawet, M., \& Kundu, S.C. (2007). Buying behaviour of rural and urban consumers in India: the impact of packaging. International Journal of Consumer Studies. 31(6)

44. Shaked, A., \& Sutton, J. (1982). Relaxing price competition through product differentiation. The review of economic studies, 3-13.

45. Singh, H.P and Singhal, R.C (1986) Packaging of processed foods under Agmark. Indian J Agric Market. 1986;22(2):15-17.

46. Sirgy, M. J. (1982). Self-concept in consumer behavior: a critical review. Journal of consumer research. 287-300.

47. Smith, W. R. (1956). Product differentiation and market segmentation as alternative marketing strategies. The Journal of Marketing. 3-8.

48. Solomon, Michael R. (1996), Consumer Behavior: Buying, Having and Being, 3d ed. Englewood Cliffs, NJ: Prentice Hall.

49. Stigler, G. J. (1950). The development of utility theory. I. The Journal of Political Economy. 307-327.

50. Verma, D.P.S. and Israney, H. (2000). Consumer attitude towards advertisement messages deliberation. Indian J Market. Vol.30.

51. W.K. Sarwade (2002) Emerging dimensions of buyers behaviour in rural area. Indian Journal of Marketing.

52. Weitz, B. A., \& Jap, S. D. Relationship marketing and distribution channels. Journal of the Academy of Marketing Science. 1995;23(4):305-320.

53. Wells, L. E., Farley, H., \& Armstrong, G. A. (2007). The importance of packaging design for own-label food brands. International Journal of Retail \& Distribution Management. 2007;35(9):677-690.

54. Yang, S., \& Raghubir, P. Can bottles speak volumes? The effect of package shape on how much to buy. Journal of Retailing. 2005;81(4):269-281.

55. Yu-Jing Chiu, Hsiao-Chi Chen, Gwo-Hshiung Tzeng, Joseph Z. Shyu (2006) Marketing strategy based on customer behaviour for the LCD-TV. International Journal of Management and Decision Making. 